Witold Chmielarz

https://orcid.org/0000-0002-9189-1675

Department of Management

Information Systems

Faculty of Management

University of Warsaw, Poland

witold@chmielarz.eu

\section{Marek Zborowski}

https://orcid.org/0000-0003-4762-127X

Department of Management

Information Systems

Faculty of Management

University of Warsaw, Poland

mzborowski@wz.uw.edu.pl

\title{
On a comparative analysis of internet banking services by the conversion method and the scoring method
}

Accepted by Editor Ewa Ziemba | Received: September 26, 2018 | Revised: March 13, 2019; June 4, 2019; June 22, 2019 | Accepted: July 2, 2019.

\begin{abstract}
Aim/purpose - The main aim of this paper is to analyse and compare implementation of two methods of websites assessment: the conversion method and the scoring method. The secondary goal is to identify the best e-banking websites in Poland in 2017 from the point of view of an individual client.

Design/methodology/approach - Based on the previous experiences in internet banking sphere authors take into account two methods - the most popular for this purpose - the scoring method and the author's conversion method. Data for research are collected using original questionnaire, verified by a pilot study. To participate in the survey, those interested had to visit a special website containing a questionnaire. The research was carried out on over 700 people from the university environment in the end of 2017.

Findings - The results obtained with both methods turned out to be similar. The study found that an economic criteria, a simplicity or an intuitiveness of navigating the website and a number of access channels are the most important factors for choosing the e-banking services by customers. Moreover, anti-crisis measures undertaken by bank (security of operations including) currently become of less importance to them.

Research implications/limitations - The main implication for researchers is the proved possibility for using the conversion method, which combines the advantages of simplicity of the gathering data with the objectivity of such methods as, for example, AHP/ANP, or PROMETHEE, ELECTRE and its usefulness for the evaluation of the bank websites. The main restrictions were of two types. The first one concerned the selection of only those two methods for comparison in this study. The second limitation - was the selection of a research sample from the academic community only.
\end{abstract}

Chmielarz, W., \& Zborowski, M. (2019). On a comparative analysis of internet banking services by the conversion method and the scoring method. Journal of Economisc \& Management, 38(4), 26-45. https://doi.org/10.22367/jem.2019.38.02 
Originality/value/contribution - The scope of this paper fills in the research gap that exists in the methods of website evaluation from the point of view of methods trying to solve this problem from a client's point of view. The next research steps will go in the direction of comparison based on the same sample of the conversion method with other popular assessment methods to identify its advantages and disadvantages for the potential user. Furthermore, a research sample now requires extension beyond the academic community that the results of the study could be fully generalised.

Keywords: electronic banking, websites' evaluation, scoring method, conversion method, website development factors.

JEL Classification: O32, M15.

\section{Introduction}

The importance of electronic banking in Poland is evidenced by the constant pace of its development. In relation to the fourth quarter of 2016, the number of individual clients who have potential access to their account increased by over $7 \%$ in relation to the fourth quarter of 2017, reaching 35.521 million users ( $92 \%$ of the population), where the number of active individual clients rose by more than $3.5 \% \%$ (see: Table 2), reaching the level of 15.889 million ( $45 \%$ of the population) (NETB@nk raport, 2018). It is the fastest growing banking sector - as indicated in the previous publications (Chmielarz \& Zborowski, 2017ab) - nothing seems to interfere with these positive trends. The increase in the absolute numbers is presented in Figure 1. Over the last ten years, the number of customers has increased by more than 25 million. There are almost $45 \%$ of active clients among all the customers with an electronic access to an account. Thus, the development in this sphere should be carefully examined and analysed.

The studies into bank websites are carried out for the following reasons:

- to assess the situation on the banking services market from the perspective of the quality of websites of each of the banks,

- to determine which of the banking websites has the highest score and the reason for such a sitiation,

- to specify and create, as well as to verify the optimal method for the bank websites' valuation,

- to analyse the characteristics of bank websites in order to create recommendations in the area of designing the websites.

The paper structure contains: a literature review, characteristics and a justification of the choice of methods adopted in the study, a description of research findings, a discussion over the analysed research data and conclusions. 
Figure 1. The number of clients with an electronic access to the account in 2001-2017 in millions in Poland

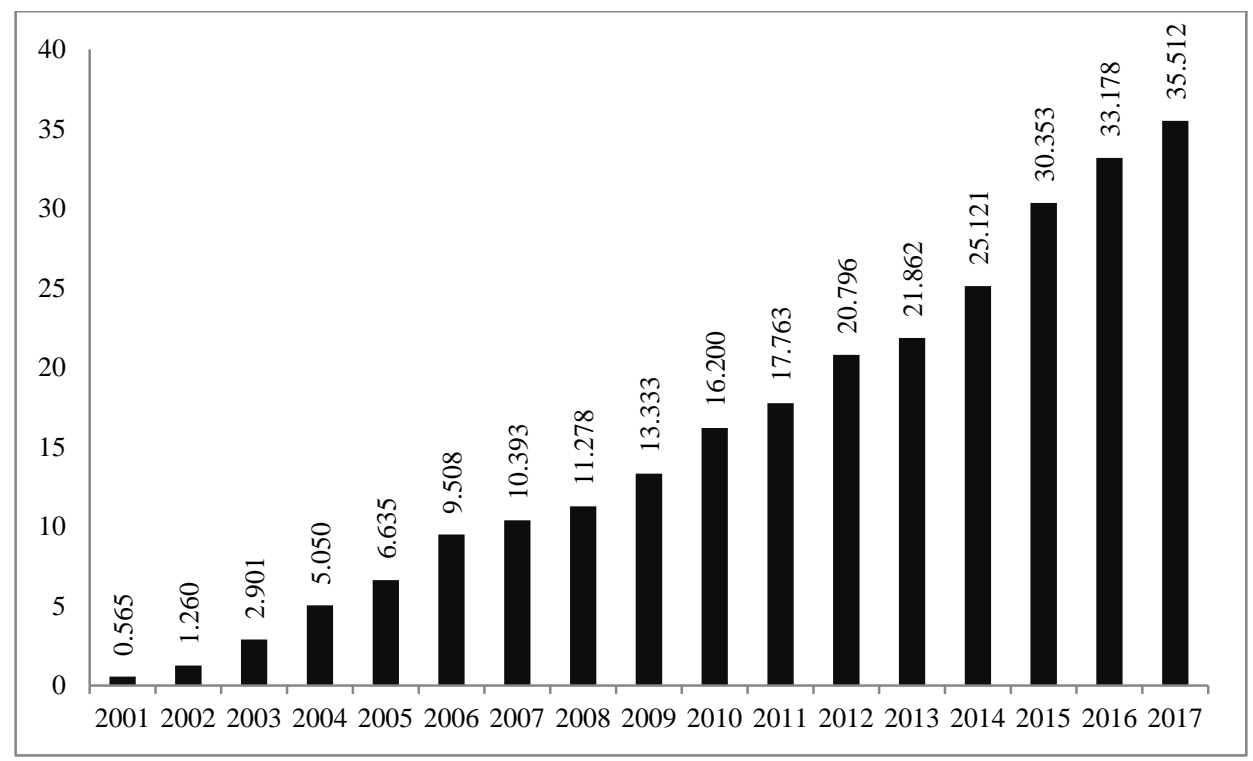

Source: Authors’ own work based on: NETB@nk raport (2018).

\section{Literature review}

The problems related to the functioning of websites, in particular, access to e-banking services, are widely discussed in the literature, and there is no single formula which would allow their unambiguous assessment and the improvement of their quality. Numerous analyses also do not indicate what effect they have on the development of banking in the countries where they are being examined. There is an ongoing process of searching for the method which would best reflect the tendencies in this sphere and, at the same time, would be most convenient from the point of view of its users. The literature review shows that WWW services of a bank may be analysed from the point of view of their: usability (site map, address catalogue) (Bauer, Hammerschmidt, \& Falk, 2005), functionality (search, navigation, content) (Yang, Cai, Zhou, \& Zhou, 2005), interactivity (accessibility and responsiveness) (Chiou, Lin, \& Perng, 2010), visualisation (colour scheme, background, graphics, text) (Mateos, Mera, Gonzales, \& Lopez, 2001), reliability (Migdadi, 2008; Miranda, Cortes, \& Barriuso, 2004), cost-effectiveness (costs of purchase, transport, the difference in prices in 
traditional and online shops) (Webb \& Webb, 2004). Most of the evaluation methods of e-banking websites are traditional scoring methods based on specific criteria sets selected by the authors of the particular research, evaluated according to a fixed scale. Among the criteria which are most frequently applied there are mostly technical and functional ones. Many of them contain factors which may be evaluated in a highly subjective way: a text clarity, an attractiveness of the colour scheme, images and photos, a speed of finding specific functions and using them) etc. In addition, some users do not treat particular criteria in an equivalent way. Some of the factors are more important than others. What is also relevant, there are numerous problems with determining preferences and relations between them. These problems - according to resent literature selection on the subject - are solved by multi-criteria methods. However, the question arises whether indeed their more complicated use may in some way be compensated for when compared to the ease and convenience in using simple methods. The authors focus on this question in the paper, too.

\section{Research methodology}

In order to carry out the research, the authors used the author's conversion method that has many advantages. Among them, it is essential to mention that it combines both the precision of the results of the multicriteria methods, such as the AHP (Kubler, Robert, Derigent, Voisin, \& Traona, 2016; Lya, Lai, Hsu, \& Shih, 2018), ANP (Becker, Becker, Sulikowski, \& Zdziebko, 2018), the ELECTRE (Corrente, Greco, \& Słowiński, 2016), the PROMETHEE (Andreopoulou, Koliouska, Galariotis, \& Zopounidis, 2018), verbal methods (Trzaskalik, 2014), TOPSIS (Chmielarz \& Zborowski, 2018), BIPOLAR (Trzaskalik, 2014). Moreover, the process of collecting data for calculations is as simple as in a case of the scoring method, and the simplicity of the result processing which is the characteristic of the scoring method. Finally, the subjectivity of scoring in the conversion method is smaller than in the case of AHP method because there is a comparison to the average score in the conversion method.

This method consists in determining the relation of each criterion to other criteria, based on averaged distances from the maximum potential value established on the basis of previous scoring evaluation. Data received from scoring evaluation are the starting point for the conversion method. The steps of the conversion method are as below. 
1. The established preference vector of the superior level criteria (first converter) has been yield by:

a) constructing a matrix of distances from the maximum value for each criterion in every website, establishing the maximum value:

$$
P_{i, \max }=\operatorname{Max}\left\{f_{i}\left(a_{j}\right), \ldots, f_{n}\left(a_{m}\right)\right\} \text { for } i=1, \ldots, n \text { and } j=1, \ldots, m \text {; }
$$

b) establishing the matrix of the distances from the maximum value:

$$
\delta\left(f_{i}\left(a_{j}\right)\right)=P_{i, \max }-f_{i}\left(a_{j}\right) \text { for } i=1, \ldots, n \text { and } j=1, \ldots, m ;
$$

c) calculating the average distance from the maximum value for each criterion:

$$
\overline{F_{i, j}}=\frac{\sum_{j=1}^{m} \delta\left(f_{i}\left(a_{j}\right)\right)}{m}
$$

d) as a result of the above operation, constructing a matrix of differences in the distance from the maximum value and the average distance according to criteria,

e) for each bank website: constructing conversion matrices - modules of relative distances of particular criteria to remaining criteria (the distance from the same criterion is 0), the obtained distances below the diagonal are the converse of the values over the diagonal,

f) averaging criteria conversion matrices - creating one matrix of average modules of values for all criteria:

$$
\bar{A}_{i, j}=\frac{\sum_{i=1, j=1}^{n, m}\left(\alpha_{i, j}-\alpha_{i+2, j}\right)}{n}
$$

g) transforming the conversion matrix of criteria into a superior preference matrix (a calculating squared matrix, adding up rows, a standardisation of the obtained preference vector, a repeated squaring, adding up rows, a standardisation of preference vector - repeating this iteration until there are minimum differences in subsequent preference vectors).

2. As a result of the above operations we establish a criteria conversion matrix $T a_{m \times 1}$. Subsequently, the authors performed a transformation of the scores presented by experts on the level of a matrix specifying expert websites' evaluations for particular criteria (second converter). The results have been obtained in an analogical way:

a) constructing a matrix of distances from the maximum value for each criterion and each website: 
- establishing the maximum value:

$$
\begin{gathered}
P_{i, \max }=\operatorname{Max}\left\{f_{i}\left(a_{j}\right), \ldots, f_{n}\left(a_{m}\right)\right\} \\
\text { for } i=1, \ldots, n \text { and } j=1, \ldots, m ;
\end{gathered}
$$

- establishing the matrix of distances from the maximum value:

$$
\delta\left(f_{i}\left(a_{j}\right)\right)=P_{i, \max }-f_{i}\left(a_{j}\right) \text { for } i=1, \ldots, n \text { and } j=1, \ldots, m
$$

b) calculating the average distance from the maximum value for each website:

$$
\overline{F_{i}}=\frac{\sum_{j=1}^{m} \delta\left(f_{i}\left(a_{j}\right)\right)}{m}
$$

c) constructing a matrix of the differences of deviations from the maximum value and the average distance of the features from the maximum;

d) for each criterion: constructing a matrix of transformations (conversions) of the differences of the average distance from the maximum value between the websites, analogically as presented above the values below the diagonal are the converse of the values over the diagonal;

e) constructing a module matrix of transformations of the differences of average distance from the maximum value between the websites, for each criterion:

$$
\bar{A}_{i, j}=\frac{\sum_{i=1, j=1}^{n, m}\left(\alpha_{i, j}-\alpha_{i+2, j}\right)}{n}
$$

f) for each module matrix of transformation of the differences of the average distance from the maximum value between the websites, squaring it, adding up rows, standardisation of the obtained ranking vector and repeating this operation until the obtained differences between two ranking vectors for each criterion will be minimal,

3. As a result of the above presented operations we obtain a conversion matrix of websites' evaluations: $T f_{m \times 1}$

a) using the obtained vectors to construct a combined ranking matrix - returning to the matrix where in;

b) its side-heading there are criteria, in the heading names of bank websites by appropriate transfer of the obtained preference vectors for each criterion;

c) multiplying the matrix obtained in such a way by the previously calculated preference vector:

$$
T^{\prime}=T f \otimes T a
$$


d) analysing final results and drawing conclusions (note: the lowest distances in this case are the most favourable, comparability adjustments to other methods can be obtained by subtracting these values from 1 and their repeated standardisation) (Chmielarz \& Zborowski, 2017b).

During the research the following procedure was adopted:

- defining sets of criteria for the evaluation of the e-banking services,

- verifying the comprehensibility and importance of criteria sets, their modification and verification of additional questions,

- adopting the methodology and evaluation criteria scale,

- placing the verified survey questionnaires on the university web servers and generating invitations for users to complete them,

- carrying out calculations by means of the scoring method, the scoring method with preferences and the conversion method,

- analysis and discussion of the findings,

- conclusions and recommendations concerning the usability of banking websites.

\section{Research findings}

The research in this paper has been conducted using the authors' own criteria sets adopted for both an electronic access to users accounts and webpage of particular banks service. The criteria sets were applied since 2006 and they were created on the basis of relevant literature and verified following consultations with the experts. The evaluation criteria were established during an internet discussion conducted with the participation of scientists and researchers representing leading universities dealing with electronic banking in Poland, based on the literature. At the moment of economic crisis of 2008, a set of anti-crisis criteria, i.e. the selected measures which - in the experts' opinion - were supposed to counteract the potential effects of the banking crisis (Chmielarz, 2010) - was added to the set of evaluation criteria used to assess the access to banking services. The second modification took place in 2017 when the authors verified the correctness, the comprehensibility and the importance of the selected criteria.

Finally, after this verification and consideration of users' comments, the criteria adopted in the studies were divided into three main groups:

- economic criteria,

- technical, visualisation and security criteria,

- anti-crisis measures. 
The respondents evaluated their preferences with regard to criteria groups as well as individual criteria. Specific criteria with preferences calculated as an arithmetic mean of the scores are presented in Table 1.

Table 1. Clients' preferences concerning particular evaluation criteria

\begin{tabular}{|c|c|}
\hline Evaluation of particular qualities & Average \\
\hline Economic & $61.72 \%$ \\
\hline The average nominal interest rate on a current account and an associated savings account & $6.77 \%$ \\
\hline Account maintenance PLN/month (the average of current and savings account) & $7.71 \%$ \\
\hline Fee for a regular electronic transfer to a bank where the user holds a bank account & $5.94 \%$ \\
\hline Fee for an electronic transfer to another bank & $6.10 \%$ \\
\hline $\begin{array}{l}\text { Payment order (the right to access the account of a debtor and collect the amount of money } \\
\text { indicated by the creditor) }\end{array}$ & $3.84 \%$ \\
\hline Fee for issuing a debit card & $4.12 \%$ \\
\hline The monthly fee for a card PLN/month (below the required limit for free transactions) & $6.12 \%$ \\
\hline The annual average interest rate on savings accounts in PLN & $5.63 \%$ \\
\hline Annual interest rate on deposits of PLN 10,000-20,000 & $4.80 \%$ \\
\hline Annual interest rate on loans of PLN $10,000-20,000$ & $4.51 \%$ \\
\hline Fees for deposits and withdrawals from ATMs/cash deposit machines in Poland & $6.18 \%$ \\
\hline Technical, visualisation and security & $32.43 \%$ \\
\hline $\begin{array}{l}\text { Additional services (e.g. an insurance, investment funds, a foreign currency account, } \\
\text { a cross-border transfer, top-up phone payments, the number of available ATMs/cash deposit } \\
\text { machines, others, like Blik payment) }\end{array}$ & $4.30 \%$ \\
\hline $\begin{array}{l}\text { Access channels (a bank branch, an internet-website, an internet-mobile application, a call centre, } \\
\text { an SMS, a helpline) }\end{array}$ & $4.84 \%$ \\
\hline $\begin{array}{l}\text { Security (a token, an ID and a password, a list of one-time passwords, a list of one-time codes, } \\
\text { a SSL protocol, an SMS with a code) }\end{array}$ & $5.89 \%$ \\
\hline Visualisation & $3.10 \%$ \\
\hline Navigation & $3.15 \%$ \\
\hline Clarity and user-friendliness & $3.75 \%$ \\
\hline Functionality & $3.35 \%$ \\
\hline User-friendliness of mobile banking (a website, an application) & $4.05 \%$ \\
\hline Anti-crisis measures & $5.85 \%$ \\
\hline $\begin{array}{l}\text { Dynamics of the changes in interest rates on deposits, loans last year, the average place from } \\
\text { the rankings, increase/decrease in the number of clients, the stability of pricing policy) }\end{array}$ & $5.85 \%$ \\
\hline
\end{tabular}

Source: Authors' own work based on the survey findings.

Among the groups, the most important set were economic criteria which obtained on average a $62 \%$ score (including the most important criterion - an account maintenance PLN/month (average: a checking and savings account) - nearly 8\%), subsequently, technical and security criteria - on average $32 \%$ (the most important security measures $6 \%$ ) as well as anti-crisis measures, on average $-6 \%$. 
Interestingly, when the respondents were asked about the importance of the evaluation criteria groups for the website evaluation they indicated much higher (15 percentage points larger) values for anti-crisis measures $-21 \%$, and lower for economic criteria 53\% (by nine percentage points and technical, visualisation and security aspects $-26 \%$ (the difference in minus amounted to 6 percentage points). The preferences specified by the clients were used in all three selected data processing views: the scoring method with preferences and in the conversion method.

The presented study constitutes the next stage of the research carried out systematically from 2006 whose primary objective is to evaluate the factors which impact the quality of websites that provide access to individual accounts in banks. Frequently, it is the quality of the website which turns out to be decisive in retaining and acquiring new customers. It is important to notice that the present ranking evaluating the quality of e-banking websites also includes economic factors which are the specific reflection of the current bank policy. In order to evaluate particular criteria in the banks which were selected by the clients, the authors used a standardised, simplified Likert scale (Likert, 1932), in which lack of a particular quality is represented by the value equal to zero, its complete fulfilment is equal to one, average fulfilment of the feature -0.5 and intermediary values such as good fulfilment is equal to 0.75 ; and sufficient fulfilment amounts to 0.25 .

The study has been conducted with the initial application of the simple scoring method and the scoring method with preferences. In the simple scoring method, the authors measure the distance from the maximum value which can be obtained (according to the adopted scale). It concerns the value of the measure of the criterion and in the sense of a distance, it is the same when we measure the distance from the first and second criterion and vice versa. However, the relationship between individual criteria is not determined. Assigning the preference scale, which adds up to the value of $100 \%$, to particular criteria (or criteria groups) can be regarded as such a measure. The normalised linear preference scale determines the participation of particular criteria in the final score. It is important to indicate that scoring methods are seen as subjective evaluation methods, even though their subjectivity appears to be limited together with the number of the interviewed respondents and the application of a preference scale. Despite their drawbacks, these methods are commonly applied and their scores are easy to interpret. The methods which are believed to be more objective, for example, the AHP method (Saaty, 1990), the Promethee II, the Electre I and III method, the TOPSIS method and other solutions are rather complex to use and sometimes it is difficult to interpret their findings. The authors' experience 
(Chmielarz, Szumski, \& Zborowski, 2011; Zborowski, 2013), mainly related to the application of the AHP method used to evaluate websites, points to the fact that the completion of survey questionnaires is very complicated from the perspective of respondents participating in studies. As a result, this may lead to illconsidered and random assessments, and the final scores may frequently be determined by the order of particular criteria. In order to eliminate such problems, the authors have devised their own evaluation method - the conversion method.

The data which are used in calculations are collected in the form of the same input tables as in the case of the scoring method. This method combines the simplicity and unambiguity of the scoring method with the precision of relational methods. It consists in establishing the relations of each criterion in relation to other criteria, based on averaged distances from the potential maximum value previously established on the basis of a scoring method. A detailed description of the method together with the algorithm of its solution may be found in the authors' previous works (Chmielarz \& Zborowski, 2013). The advantages of this method include:

- the ease of use (similar to the application of a scoring method) which results from the fact that in the survey, there are questions related to a subjective assessment of a particular element;

- in the case of a large number of evaluation criteria or alternatives there is no significant increase in the number of questions included in the questionnaire (as in the case of the AHP method);

- the possibility of an application of this method in the studies with the participation of non-experts in the field;

- there are no measures as e.g. in the case of the ELECTRE method (Buchanan, Sheppard, \& Lamsade, 2013), the TOPSIS method (Wątróbski, Jankowski, Karczmarczyk, \& Ziemba, 2017) - veto threshold, which may not be fully understandable for the respondent and the final scores, i.e. the computed assessments of the examined objects are easy to interpret.

The usefulness of the conversion method was verified a few times in the research into the applications of modern technologies, e.g. m-banking, m-payments or the transformation or development of websites accessed via mobile devices. This results in the scores which are similar to the AHP method (Saaty, 1990) - its application seems efficient and worthwhile in relation to the scoring methods. The conversion method (Chmielarz \& Zborowski, 2013) has been chosen to verify the results of the scoring method due to the possibility of using the previously applied input tables (similarly to the conversion methods) in the calculations. Moreover, the findings are relatively easy to interpret when compared to other multi-media methods. 
Based on the above assumptions, in December 2017 the authors conducted the research into the quality of the e-banking websites of the banks which are the most popular among individual clients in Poland. The sample of the study covered 721 respondents. Among them, there were 83 (nearly $12 \%$ of the population) people holding and evaluating two accounts in two different banks, 38 respondents (5\%) having and assessing three accounts in three different banks. In total, the survey participants carried out 1002 evaluations of 28 banking websites. Among the 28 websites, seven responses concerned one bank, none of them was complete and correct, and thus the authors used 21 banks in further analyses. Correct responses were provided by 290 individuals (40\% of the respondents), out of which 16 (almost 6\%) people evaluated two websites, and four participants (over 1\%) assessed three of them. In total, there were 334 fully and correctly completed evaluations of banking websites (33\% of all completed survey questionnaires). In the examined population, the dominating number of people had accounts in three types of banks: internet banks (e.g. mBank, Inteligo PKO BP), modern banks (e.g. AliorBank or Millenium) and the biggest banks (e.g. PKO BP, BZ WBK).

This research was a case of a purposeful sampling - the studies were carried out with the participation of students of last years of specialisation studies at the University of Warsaw, following a series of lectures on e-business website evaluation. The participants were 19-50 years old students of the Faculty of Management of the University of Warsaw, (specialisations in Accounting, Finance and Insurance and Management) from randomly selected student groups. More than $98 \%$ of respondents were $18-25$ years old, which could have influenced the results of the survey (15.6\% of the population in Poland are potential clients of e-banking, including over $50 \%$ of active clients in 2016) (mBank, 2015). Among the survey participants, there were $72 \%$ of women and $28 \%$ of men. The secondary education was declared by over $96 \%$ of the examined population, BA or BSc studies by less than $3 \%, 1 \%$ declared that they completed studies of the second cycle. The majority (55\%) described themselves as working students, $45 \%$ as students. Most people (26\%) stated that their place of birth was a town below 50,000 inhabitants, almost the same number of respondents - cities with more than 500,000 residents, and $23 \%$ - villages.

The greatest number of electronic access accounts was indicated in the case of the clients of mBank (15\%), then iPKO PKO BP S.A. (13\%) and Millenium $(12 \%)$. The smallest shares in the examined group were clients holding accounts in: BGŻ Optima and Orange Finance (approximately 1\% each). The spread be- 
tween the smallest and the largest share of electronic access to accounts in particular banks in the entire sample amounts to 14\%. Only in six out of 21 banks, the participation of clients was above the average amounting to $5 \%$.

\section{Discussion}

To carry out an analysis based on the conversion method, the authors used the input tables where each of the clients evaluated the bank offers related to selected e-banking services and fees connected with using bank accounts which can be managed via the internet. Subsequently, on the basis of the completed survey questionnaires, one summary table of the averaged criteria evaluations generated by the users was created. On this basis, the authors were able to carry out relevant analyses and discuss the obtained scores.

In the present study, the applied conversion method produced interesting results. Due to a large degree of discrepancy with reference to the users' opinions on the e-banking services in the same banks, not only did it average and reduce the differences, but also, taking into account the relationship between the maximum and average values obtained as a result of calculations, it caused a significant change in the scores. Previously, a similar effect was achieved using the Saaty's AHP method. 'Flattening' the extreme opinions allowed the authors to obtain results closer to the opinions of the most active clients than in the case of the scoring method. In the case of the classification carried out with the application of the conversion method, the top positions were taken by the banks which pursue the most stable policy from the perspective of the clients. Thus, these were not the services which relatively recently emerged in the market, since the users' opinions concerning their activity are still largely unstable (a wide spread of responses). Here, the results were markedly lower for the banks which ranked higher in the scoring evaluation.

The obtained ranking is presented in Table 2. The analysis of the ranking allows to observe that the leading alternative Bank Millennium SA obtained approximately almost a triple score of the worst alternative BGŻ Optima (8.40\% compared to $3.07 \%$ ). Nevertheless, the second and third alternative in the ranking (Raiffeisen Bank Polska SA and Nest Bank - respectively) obtained only slightly smaller score $(8.08 \% \%$ and $6.97 \%$ than the leading bank). The average score was $4.76 \%$. Eleven alternatives obtained more than average score and ten alternatives scored worse than average. 
Table. 2. Comparison of rankings for the 21 banks, for conversion and scoring method

\begin{tabular}{|c|c|c|c|c|}
\hline \multirow{2}{*}{ Banks/Method } & \multicolumn{2}{|c|}{ Scoring method } & \multicolumn{2}{|c|}{ Conversion method } \\
\hline & $\% \%$ of share* & Place in ranking & $\% \%$ of share* & Place in ranking \\
\hline Alior Bank SA & $4.92 \%$ & 6 & $3.03 \%$ & 14 \\
\hline Bank Millennium SA & $4.97 \%$ & 2 & $8.40 \%$ & 1 \\
\hline Bank Ochrony Środowiska SA & $4.55 \%$ & 19 & $4.60 \%$ & 12 \\
\hline Bank Pocztowy SA & $4.27 \%$ & 21 & $2.30 \%$ & 18 \\
\hline Bank Polska Kasa Opieki SA & $4.70 \%$ & 14 & $6.71 \%$ & 5 \\
\hline Bank Zachodni WBK SA & $4.61 \%$ & 16 & $5.39 \%$ & 8 \\
\hline BGŻ BNP Paribas SA (BNP) & $4.76 \%$ & 13 & $2.15 \%$ & 20 \\
\hline BGŻ Optima & $4.78 \%$ & 12 & $3.07 \%$ & 21 \\
\hline Credit Agricole Bank Polska SA & $4.47 \%$ & 20 & $4.22 \%$ & 13 \\
\hline Deutsche Bank Polska SA & $4.55 \%$ & 18 & $2.29 \%$ & 19 \\
\hline Euro Bank SA & $4.89 \%$ & 8 & $3.01 \%$ & 15 \\
\hline Getin Noble Bank SA & $4.81 \%$ & 11 & $5.31 \%$ & 10 \\
\hline ING Bank Śląski SA & $4.96 \%$ & 3 & $5.04 \%$ & 11 \\
\hline mBank & $4.95 \%$ & 5 & $6.81 \%$ & 4 \\
\hline Nest Bank & $4.83 \%$ & 10 & $6.97 \%$ & 3 \\
\hline Orange Finance & $5.07 \%$ & 1 & $5.81 \%$ & 7 \\
\hline PKO Bank Polski SA (Inteligo) & $4.60 \%$ & 9 & $6.35 \%$ & 6 \\
\hline PKO Bank Polski SA (iPKO) & $4.84 \%$ & 17 & $2.74 \%$ & 16 \\
\hline Raiffeisen Bank Polska SA & $4.95 \%$ & 4 & $8.08 \%$ & 2 \\
\hline T-Mobile Usługi Bankowe & $4.63 \%$ & 15 & $2.39 \%$ & 17 \\
\hline Volkswagen Bank Polska SA & $4.91 \%$ & 7 & $5.35 \%$ & 9 \\
\hline
\end{tabular}

* Where: $\% \%$ of share means percentage share of result obtained for given bank in possible maximum result. Source: Authors' own work.

It appears to be the result, on the one hand, of the increased awareness of the clients, and on the other, this was due to the fact that in the case of 'their' e-banking websites the changes (not always seen as improvements) were too rarely introduced. Moreover, the results of the ranking have changed, sometimes to a considerable degree (Figure 2, the results were brought to comparability). In case of the conversion method, Bank Millennium SA was a leader in the ranking, moving from the previous second position; the second place was taken by Raiffeisen Bank Polska SA (from the fourth position), and the subsequent positions were taken by the banks which took leading positions in the 'scoring' ranking: Orange Finance, Bank Millennium SA, and ING Bank Śląski SA, fell by some positions (for example ING Bank Śląski SA - eight positions down). Bank Pocztowy, which took the last position in the scoring method, went to the eighteen position now, and BGŻ Optima - last place now was twelve in the previous ranking, thus fall by nine places. 
Figure 2. Comparison of the evaluations carried out with the scoring method and the conversion method for ten most popular banks in Poland in 2017

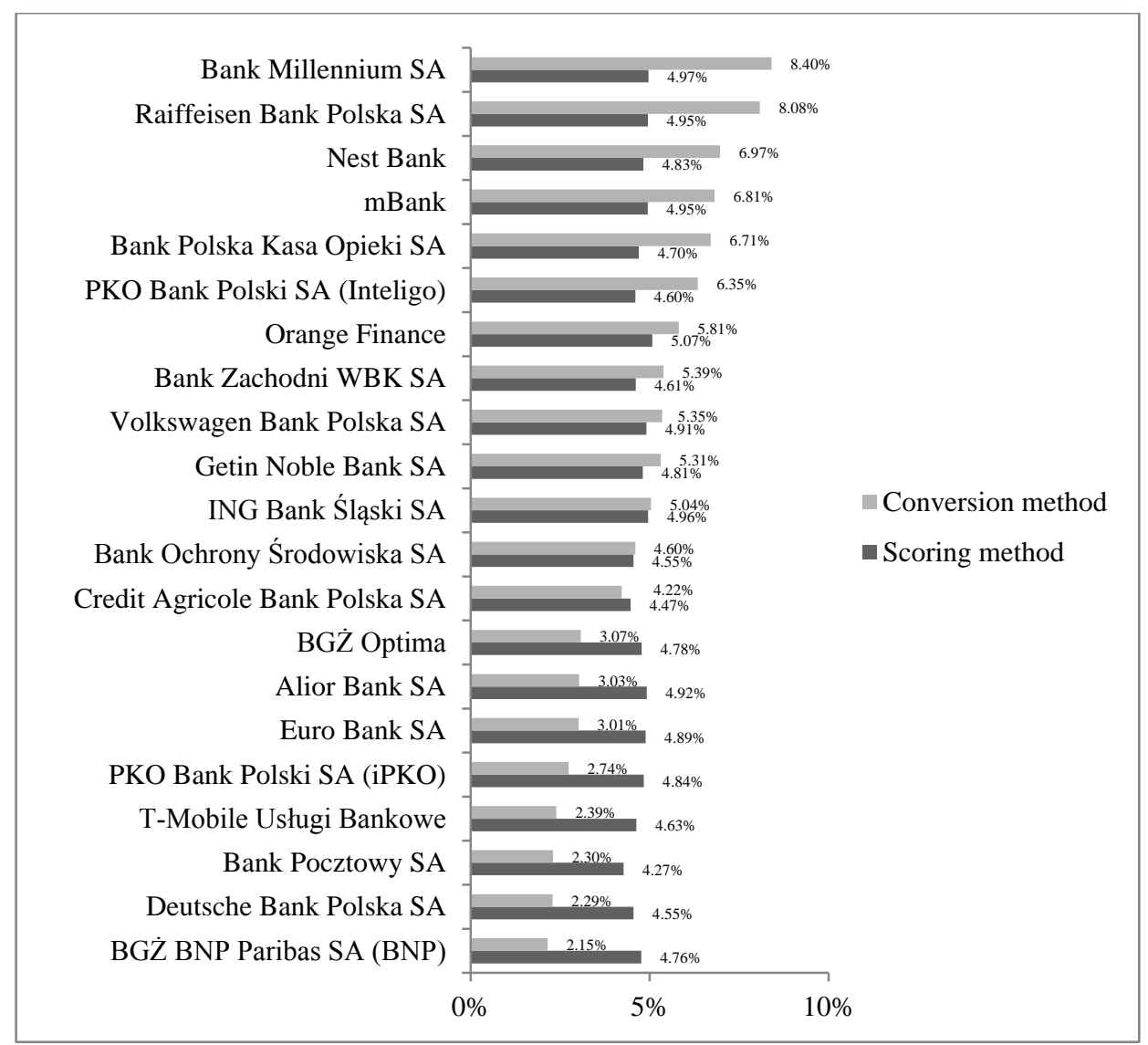

The position of the 'oldest' internet banks: mBank, PKO Bank Polski SA (Inteligo), Volkswagen Bank Polska SA appears to be the most stable - the difference between the scores slightly exceeds three percentage points.

The first position of the Bank Millennium SA in the conversion method was caused by the highest score in both the annual average interest rate on savings accounts in PLN and the monthly fee for a card PLN/month (below the required limit for free transactions) criterion in compression to the others. The last position of the BGZ Optima bank was caused by the smallest influence (the lowest score among other criteria) of the total score in the functionality and the account maintenance PLN/month (the average of a current and savings account) criteria. 
Moreover, the differences in positions reached by the banks in both types of rankings result from the fact that the scoring method consists in summing up the bank's results and the conversion method uses the distances from the highest achievable score in a given criterion.

In the evaluation carried out with the conversion method, the discrepancy between the scores amounted to 5.33\%, in the standardised scoring method it was about five times lower (the difference of one of the percentage point was indicated).

The results of the calculations presented in Table 2 show that the use of the conversion method produces basically similar results with regard to the ranking as using the scoring method. The main differences in the results rely on the fact that using the conversion method shows the differences between the maximum possible grades in individual criteria and average grades. Hence, banks, whose users admit very high (enthusiastic) assessments in individual criteria compared to users of other banks with more moderate ratings, move to higher positions than in the scoring method. This confirms the thesis that if the initial set is the same - as in this case - then the application of a simpler method is comparable to the use of more complex methods (here: the conversion method), and it does not require any additional complicated calculations. But the interpretation of the findings is not quite easily possible and convenient. However, we have to do with possibility of comparing relations between the highest and average assessment of each criterion in the most popular Polish banks.

\section{Conclusions}

The presented analysis has shown the diversity of the opinions of individual clients on the usability of banks websites, in particular, their views concerning the selection and use of websites to meet the daily needs of users related to banking services. At this point, it is important to indicate that the demand is high and greatly diversified. At the end of 2017, in Poland, there were 32.6 million of e-banking clients, including 14.7 million of active customers (at least one contact with checking and savings account per month) (Boczoń, 2018b), including 8.9 million of clients using mobile devices to contact the bank (website or application) (Boczoń, 2018a), including 2.2 million users of strictly mobile banking (only via a smartphone application) (Boczoń, 2018c). Unfortunately, this still means that the percentage share of active users in Poland in relation to all e-banking users gives Poland the $19^{\text {th }}$ place in the EU (Eurostat, 2018). 
The number of clients and potential clients may grow due to the following trends:

- variability of customer experience, which represents the total of all client's experiences and emotions which are associated with a given product or company,

- development of interactive support in the course of performing financial operations,

- the possibility to carry out orders and banking transactions using one's voice,

- personalised and customised sale of products and services,

- the rise of awareness of the blockchain solution, used to store and send information about online transactions,

- the wide use of biometric tools; in the near future, they will verify a client, e.g. when logging in to the account, opening a bank account or authorising transactions (Leś, 2018).

Even in 2017, the authors dealt mainly with the first trend, yet the bank analysts predict that this year the remaining trends will be taking a dominating position.

In this paper, the authors have not differentiated the clients with regards to the electronic devices they use and the tools by means of which they contact their banks. Nevertheless, they were evaluated from the point of view of the device which made it possible to communicate with the bank. The evaluation of the devices allowed drawing the following conclusions:

1) It appears that mobile access to banking services is the most important phenomenon in the electronic banking market. This is evidenced by the position of the Orange Finance in the scoring method ranking. In the conversion method, the Orange Finance was seventh because customers of this bank give it more moderate grades then customers of long existing internet banks (mBank) or marketing aggressive banks (Nest Bank).

2) The position of the Bank Polska Kasa Opieki SA has significantly decreased in relation to other rankings, which may result from so called 'repolonisation' in 2017.

3) The vast majority of active bank clients (62\%) believe that economic criteria, i.e. the first three positions among all the most frequently used services are the most significant criteria in the evaluation of internet access to banking.

4) However, more and more people admit that they are inclined to consider the ease of access to mobile banking (nearly 80\%) and the number of access channels $(82 \%)$ when selecting a given website. 
5) The issues related to anti-crisis measures also fell below the average (73\%), and it emerges that users slowly start to forget about the crisis of 2008.

6) The scale of inactive clients (approximately $45 \%$ according to estimates presented by the Polish Bank Association (ZBP)) appears to be alarmingly large in relation to those customers who can potentially use electronic banking. It is true that a few years ago the estimates did not exceed $20 \%$, but the pace of increase in the customer activity in this field (considering the access to e-banking services of more than $85 \%$ of the Polish population) is still very slow.

The fact that starting from last year the long-awaited discrimination between banking services via mobile devices and mobile banking induces the authors to conduct thorough analyses of the 'strictly' mobile banking carried out by means of the applications running on smartphones and tablets. The diversity in the sphere of banks operating independently or in alliances with mobile operators also necessitates the consideration of the justification of making a separate evaluation of bank's website, e-banking used via mobile devices and mobile banking. The problem consists in the fact that clients who use mobile devices are not always fully aware that connecting to a website using a mobile device is not mobile banking. The second problem is that in the course of the previously conducted studies (Chmielarz \& Zborowski, 2017ab), clients claimed that they only engage in low-value transaction when using a smartphone (by means of a website or application), and the remaining operations are carried out by means of personal and desktop computers, frequently not noticing or recording which of these transactions are conducted by means of applications. Thus, this area requires continuous and ongoing research in the field.

\section{References}

Andreopoulou, Z., Koliouska, Ch., Galariotis, E., \& Zopounidis, C. (2018). Renewable energy sources: Using PROMETHEE II for ranking websites to support market opportunities. Technological Forecasting and Social Change, 131, 31-37. https://doi. org/10.1016/j.techfore.2017.06.007

Bauer, H., Hammerschmidt, M., \& Falk, T. (2005). Measuring the quality of e-banking portals - an empirical investigation. International Journal of Bank, 23(2), 153-175. https://doi.org/10.1108/02652320510584395

Becker, J., Becker, A., Sulikowski, P., \& Zdziebko, T. (2018). ANP-based analysis of ICT usage in Central European enterprises. Procedia Computer Science, 126, 2173 2183. https://doi.org/10.1016/j.procs.2018.07.231

Boczoń, W. (2018a, February). Rynek bankowości mobilnej - IV kw. 2017 [Online banking market - Q4 2017]. Raport PRNews.pl. Retrieved from https://prnews.pl/ raport-prnews-pl-rynek-bankowosci-mobilnej-iv-kw-2017-433527 
Boczoń, W. (2018b, March). Rynek bankowości internetowej - IV kw. 2017 [Online banking market - Q4 2017]. Raport PRNews.pl. Retrieved from https:// prnews.pl/raport-prnews-pl-rynek-bankowosci-internetowej-iv-kw-2017-434184

Boczoń, W. (2018c). Liczba klientów mobile only - IV kw. 2017 [Number of mobile only clients - Q4 2017]. Raport PRNews.pl. Retrieved from https://prnews.pl/ raport-prnews-pl-liczba-klientow-mobile-only-iv-kw-2017-433554

Buchanan, J., Sheppard, P., \& Lamsade, D. V. (2015). Project ranking using ELECTRE III. Retrieved from http://citeseerx.ist.psu.edu/viewdoc/download?doi=10.1.1.493. $6585 \& \mathrm{rep}=\mathrm{rep} 1 \&$ type $=\mathrm{pdf}$

Chiou, W. Ch., Lin, Ch.-Ch., \& Perng, Ch. (2010). A strategic framework for website evaluation based on a review of the literature from 1995-2006. Information \& Management, 47(5-6), 282-290. https://doi.org/10.1016/j.im.2010.06.002

Chmielarz, W. (2010). Methodological aspects of the evaluation of individual e-banking services for selected banks in Poland. In M. Pańkowska (Ed.), Infonomics for distributed business and decision-making environments. Creating information system ecology (pp. 201-2016). IGI Gobal. https://doi.org/10.4018/978-1-60566-890-1.ch011

Chmielarz, W., Szumski, O., \& Zborowski, M. (2011). Kompleksowe metody ewaluacji jakości serwisów internetowych [Comprehensive quality evaluation methods for Internet websites]. Warszawa: Wydawnictwo Naukowe Wydziału Zarządzania Uniwersytetu Warszawskiego.

Chmielarz, W., \& Zborowski, M. (2013). Conversion method in comparative analysis of e-banking services in Poland. In A. Kobyliński \& A. Sobczak (Eds.), Information Systems and Services. Lecture Notes in Business Information Processing, 158, 227-240. https://doi.org/10.1007/978-3-642-40823-6_18

Chmielarz, W., \& Zborowski, M. (2017a). Analysis of the use of electronic banking and e-payments from the point of view of a client, in annals of computer science and information systems. In M. Ganzha, L. Maciaszek, \& M. Paprzycki (Eds.), Proceedings of the 2017 Federated Conference on Computer Science and Information Systems (pp. 965-969), September 3-6, 2017, Praha, Czech Republic. Warsaw: PTI. https://doi.org/10.15439/978-83-946253-7-5

Chmielarz, W., \& Zborowski, M. (2017b). Comparative analysis of electronic banking websites in Poland in 2016. In S. Wrycza \& J. Maślankowski (Eds.), Information systems: Research, development, applications, education (Lecture Notes in Business Information Processing, Vol. 300, pp. 43-56). https://doi.org/10.1007/978-3319-66996-0_4

Chmielarz, W., \& Zborowski, M. (2018). Analysis of e-banking websites' quality with the application of the TOPSIS method - a practical study. Procedia Computer Science, 126, 1964-1976. https://doi.org/10.1016/j.procs.2018.07.256

Corrente, S., Greco, S., \& Słowiński, R. (2016). Multiple criteria hierarchy process for ELECTRE Tri methods. European Journal of Operational Research, 252(1), 191-203. https://doi.org/10.1016/j.ejor.2015.12.053

Eurostat. (2018). E-banking and e-commerce. Retrieved from http://appsso.eurostat.ec. europa.eu/nui/show.do?dataset=isoc_bde15cbc\&lang=en 
Kubler, S., Robert, J., Derigent, W., Voisin, A., \& Traona, Y. (2016). A state-of the-art survey \& testbed of fuzzy AHP (FAHP) applications. Expert Systems with Applications, 65(15), 398-422. https://doi.org/10.1016/j.eswa.2016.08.064

Leś, T. (2018). Jakie innowacje przyniesie bankowości 2018 rok? [What innovations in banking will bring 2018?]. Asseco News. Retrieved from https://asseconews.pl/ jakie-innowacje-przyniesie-bankowosci-2018-rok/

Likert, R. (1932). A technique for the measurement of attitudes. Archives of Psychology, 140, 5-55.

Lya, P. T. M., Lai, W.-H., Hsu, Ch.-W., \& Shih, F.-Y. (2018). Fuzzy AHP analysis of Internet of Things (IoT) in enterprises. Technological Forecasting and Social Change, 136, 1-13. https://doi.org/10.1016/j.techfore.2018.08.016

Mateos, M. B., Mera, A. C., Gonzales, F. J., \& Lopez, O. R. (2001). A new web assessment index: Spanish universities analysis. Internet Research: Electronic Application and Policy, 11(3), 226-234. https://doi.org/10.1108/10662240110396469

mBank. (2015). Najbardziej udany wzrost organiczny $w$ Polsce [The most successful organic growth in Poland]. Retrieved from https://www.mbank.pl/pobierz/mspkorporacje/wyniki-finansowe/introduction_to_mbank_pol_2015_q3.pdf?noredir

Migdadi, Y. K. (2008). Quantitative evaluation of the internet banking service encounter's quality: Comparative study between Jordan and the UK retail banks. Journal of Internet Banking and Commerce, 13(2), 1-8. Retrieved from http://www. icommercecentral.com/open-access/quantitative-evaluation-of-the-internet-banking -service-encounters-quality-comparative-study-between-jordan-and-the-uk-retailbanks.php?aid=38440

Miranda, F. J., Cortes, R., \& Barriuso, C. (2004). Quantitative evaluation of e-banking web sites: An empirical study of Spanish banks. The Electronic Journal Information Systems Evaluation, 2(9), 73-82.

NetB@nk raport. (2018). Bankowość internetowa i mobilna płatności bezgotówkowe [Online banking and mobile e-payments]. Retrieved from https://zbp.pl/public/ repozytorium/wydarzenia/images/czerwiec_2018/konf/Raport_Netbank_Q1_201806 26T14.30.pdf

Saaty, T. L. (1990). Decision making for leaders: The analytic hierarchy process for decisions in a complex world. Pittsburgh, PA: RWS Publications.

Trzaskalik, T. (2014). Wielokryterialne wspomaganie decyzji. Przegląd metod i zastosowań [Multi-criteria decision making support. Review of methods and applications]. Zeszyty Naukowe Politechniki Śląskiej. Organizacja i Zarządzanie, 74(1921), 239-263.

Wątróbski, J., Jankowski, J., Karczmarczyk, A., \& Ziemba, P. (2017). Integration of eyetracking based studies into e-commerce websites evaluation process with eQual and TOPSIS methods. In S. Wrycza \& J. Maślankowski (Eds.), Information Systems: Research, Development, Applications, Education: 10th SIGSAND/PLAIS EuroSymposium 2017, Gdansk, Poland, September 22, 2017, Proceedings (Lecture Notes in Business Information Processing, Vol. 300, pp. 56-80). https://doi.org/ 10.1007/978-3-319-66996-0_5 
Webb, H. W., \& Webb, L. A. (2004). SiteQual: An integrated measure of Web site quality. Journal of Enterprise Information Management, 17(6), 430-440. https:// doi.org/10.1108/17410390410566724

Yang, Z., Cai, S., Zhou, Z., \& Zhou, N. (2005). Development and validation of an instrument to measure user perceived service quality of information presenting Web Portals. Information \& Management, 42(4), 234-254. http://doi.org/10.1016/ j.im.2004.03.001

Zborowski, M. (2013). Modelowanie witryn internetowych uczelni wyższych o profilu ekonomicznym [Modelling websites of economic universites] (doctoral dissertation under the supervision of W. Chmielarz). Faculty of Management at the University of Warsaw. 